\title{
High Growth Aspirations of Nascent Entrepreneurs: Why Do They Fall?
}

\begin{abstract}
Krzysztof Zięba*
Intention-based research becomes more and more popular in various domains, including entrepreneurship. Achieving growth by a business must be planned or at least consciously accepted by the business owner. That is why it is vital to take growth intentions into account when trying to predict growth of business. Personal attitude of an entrepreneur towards growth is important from the very beginning of business operations or even before that. Nascent entrepreneurs also have their growth aspirations during the business founding process, and those aspirations affect both this process and the subsequent growth of a new business.

The aim of this paper is to investigate growth aspirations of nascent entrepreneurs in comparison to the attitudes of actual entrepreneurs towards the growth of their businesses. Additionally, this paper offers indirect answers to the question on what kind of mechanism - Lamarckian adaptation or Darwinian negative selection - may be responsible for a gradual lowering of growth aspirations expressed by nascent entrepreneurs.
\end{abstract}

Keywords: entrepreneurship, nascent entrepreneurs, growth, growth aspirations.

Submitted: 24.08.2016 | Accepted: 26.10.2016

\section{Wysokie aspiracje wzrostowe preprzedsiębiorców: dlaczego spadają?}

Rola intencji jako przedmiotu badań naukowych zyskuje na znaczeniu w obrębie różnych dziedzin, wtaczajac $w$ to także przedsiębiorczość. Osiaganie wzrostu przez firme musi być wynikiem działań planowanych lub przynajmniej akceptowanych przez wtaściciela firmy. Dlatego intencje wzrostowe musza być brane pod uwage, gdy chce się przewidzieć wzrost firmy. Osobisty stosunek przedsiębiorcy do kwestii wzrostu firmy jest wazny od samego poczatku jej funkcjonowania, a nawet wcześniej. Preprzedsiębiorcy w trakcie procesu założycielskiego również maja pewne aspiracje wzrostowe, które moga oddzialywać zarówno na sam proces założycielski, jak i na późniejszy wzrost firmy.

Celem tego artykułu jest zbadanie aspiracji wzrostowych preprzedsiębiorców i porównanie ich z nastawieniem do wzrostu wykazywanym przez faktycznie działajacych przedsiębiorców. Przeprowadzone badanie pozwala również pośrednio odpowiedzieć na pytanie o to, jaki mechanizm jest odpowiedzialny za stopniowe obniżanie się aspiracji wzrostowych: adaptacja (zgodnie z teoria Lamarcka) czy negatywna selekcja (zgodnie z teoria Darwina).

Słowa kluczowe: przedsiębiorczość, preprzedsiębiorcy, wzrost, aspiracje wzrostowe.

Nadesłany: 24.08.2016 | Zaakceptowany do druku: 26.10.2016

JEL: L21, L25, L26

Krzysztof Zięba, PhD - Faculty of Management and Economics, Gdańsk University of Technology. Mailing address: Faculty of Management and Economics, Gdańsk University of Technology; ul. Narutowicza 11/12, 80-233 Gdańsk; e-mail: kzieba@zie.pg.gda.pl; orcid ID: 0000-0003-4307-9022. 


\section{Introduction}

Growth of a business is a result of deliberate actions of an entrepreneur, assisted by sufficient resources and favourable conditions offered by the environment. Despite many various theories of growth, differences between growth theories aimed at large enterprises and small and medium-sized enterprises (SMEs), different concepts regarding how to measure growth of a business and different sets of growth factors, one element remains unchanged: growth can only be possible when it is accepted by the business owner. The process of growing one's business is an intentional process. Favourable external conditions may happen by chance, but the pursuance of a growth process is always deliberate.

The answer to the "to grow or not to grow" question is not obvious. Growing a business brings about many advantages, but it results also in threats and important shortcomings. The intent to grow a business is, therefore, the outcome of the evaluation (conscious or unconscious) of pros and cons. Since the intent to grow is so important to the process of growing a business, an increasing body of literature is recently devoted to this topic.

The intent to grow is important for existing businesses. When it comes to individuals taking actions aimed at starting their own business (nascent entrepreneurs), it is too early to talk about intentions. The process of growth is only a potential possibility that may be realised one day, when the business is already started. However, the attitude of nascent entrepreneurs towards growth also appears to be important. This is where "growth aspirations" come into play.

The aim of this paper is to investigate growth aspirations of nascent entrepreneurs in comparison to the attitudes of actual entrepreneurs towards the growth of their businesses. Additionally, since growth aspirations of nascent entrepreneurs are higher than those of actual entrepreneurs, this paper offers indirect answers to the question on what kind of mechanism may be responsible for a gradual lowering of growth aspirations expressed by nascent entrepreneurs.

\section{Growth of Businesses}

Growth issues, especially regarding the small and medium-sized enterprise (SME) sector, are popular in the contemporary literature. However, there is no one unequivocal theory precisely defining growth and its measures or determining the reasons why businesses generally grow and, more specifically, why some of them grow whereas others do not.

Instead of one universal theory, there are numerous theories focusing on particular problems. Among single factors possibly affecting growth of a business are: education, entrepreneurial experience, social and professional networks, planning, motivations, geographical location, etc. (Wasilczuk and Zięba, 2014). There were also some attempts to develop more integrative and complex growth theories, starting from the early nineties of the last century (Storey, 1994). For an extensive literature review on growth see: Coad(2007) and Wasilczuk (2005). Those integrative theories, even though they seem to be quite sophisticated when compared with single factor theories, lack one important factor influencing growth of enterprises: the owner's intention to grow.

Intention-based research becomes more and more popular in various domains, also including entrepreneurship and entrepreneurship education (Kuehn, 2008). It is believed that entrepreneurial behaviour is preceded by entrepreneurial intentions, and that is mostly because entrepreneurial process is a planned activity. Achieving growth by a business is of the same nature. It must be planned or at least consciously accepted by the business owner. That is why it is vital to take growth intentions into account when trying to predict growth.

The theoretical cornerstones of intention-based research in the entrepreneurship domain are two major models: Shapero's Entrepreneurial Event (SEE) model and the Theory of Planned Behaviour (TPB). The SEE model is based on the idea that human behaviour is governed by inertia, and this inertia may be broken by what is called a displacement event. Depending on perception (perceived desirability and feasibility) and propensity to act, entrepreneurial intentions may appear (Krueger, 1993). Similarly, life experiences and subsequent perceptions that

Wydział Zarządzania UW ～DOI 10.7172/1733-9758.2017.23.9 
are drawn from those experiences, combined with personal characteristics, influence intentions, according to the Theory of Planned Behaviour (TPB). Those factors shape intentions, and intentions, in turn, decide upon actual behaviour (Ajzen, 1985). The TPB approach has been tested across many domains (not only entrepreneurship) and seems to be very suitable for predicting actual behaviours on the basis of given explanatory variables and behavioural intention. Both models were taken into account when building the intentional model of growth for SMEs - see Figure 1.

Four sets of factors, traditionally connected with growth, are linked both to the actual growth of a business and to growth intention. Growth intention is a starting point for the growth process, which is facilitated by the above-mentioned groups of factors. The model has been tested using data from the Pomeranian Economic Observatory (Wasilczuk, Zięba and Dominiak, 2008).

\section{Growth Intentions and Growth Aspirations}

Growth intentions, as can be seen in the previous section, play an important role in achieving the actual growth of a business. Personal attitude of an entrepreneur towards growth is important from the very beginning of business operations or even before that, when first actions towards setting up a business are taken. Nascent entrepreneurs have their growth aspirations during the business founding process, and it seems likely that those aspirations affect both this process and the subsequent growth of a new business (Zięba, 2015).

Some data suggest that growth aspirations of nascent entrepreneurs are significantly higher than those of actual entrepreneurs (Bager and Schott, 2004). This poses a question on why growth aspirations tend to decrease when nascent entrepreneurs turn into actual ones. There are possibly two explanations, both based on the evolutionary vision of this change, but employing different mechanisms. The first one assumes Darwinian vision that negative selection takes place, eliminating those with high growth aspirations. Greater growth aspirations require more resources; hence, it is more difficult to start such a business. High growth aspirations may also be more typical of highly innovative and non-standard business ideas, which on one hand creates greater possibilities for growth, but on the other hand makes business more risky and more likely to fail. The other vision is based on Lamarckian idea of adaptation. Initially high growth aspirations are, in line with this vision, gradually reduced under the influence of entrepreneurial experience gained while running a business. There is no clear answer so far as to which of those mechanisms is responsible for decreasing

Figure 1. Intentional model of growth

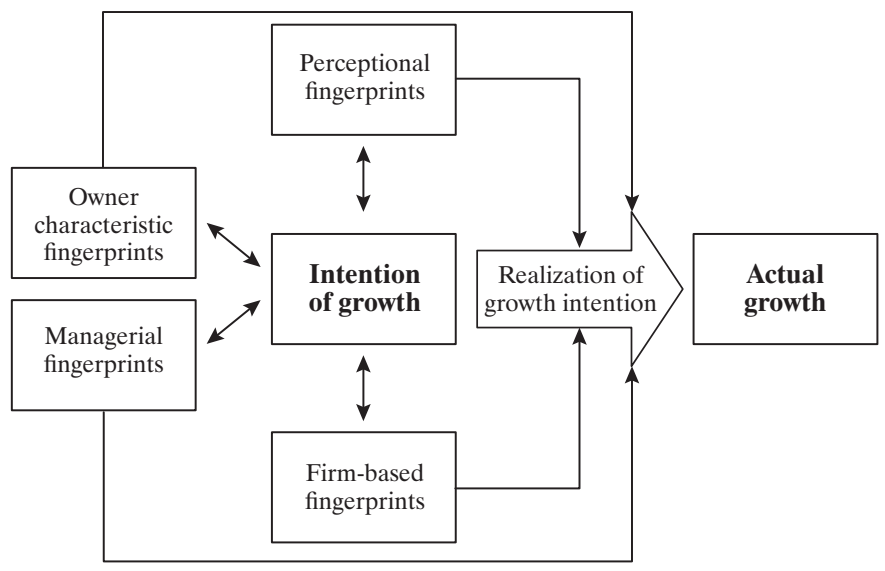

Source: Wasilczuk, Zięba and Dominiak, 2008. 
growth aspirations, but Bager and Schott (2004) tend to point to the negative selection mechanism.

Growth aspirations are usually examined with the use of two approaches. The first one is based on PSED research and uses a matrix linking start-up motivations and growth aspirations, as can be seen in Figure 2. Start-up motivations are broken here into two major types: opportunity and necessity, thus reflecting the typical dichotomy between opportunity-based and necessitybased entrepreneurship. The other dimension of the matrix separates small businesses from entrepreneurial businesses. Small businesses are defined here as those that are small enough to be managed solely by the owner or with help from a few key employees. Entrepreneurial businesses are those that are set up with the intention of an unrestricted growth - they are meant to be eventually as big as possible. PSED data suggest both dimensions of the matrix have their dominants: the opportunitybased motivation is more popular than the necessity-based one ( $86 \%$ vs. $14 \%$ ), and low growth aspirations are more frequent than those typical of entrepreneuria businesses (79\% vs. 21\%). The most popular group among new ventures is, therefore, the opportunity-based small business venture (OSBV) $-67 \%$. It should be noted, however, that entrepreneurial businesses are nearly five times more often found among opportunity-based ventures than among necessity-based ones $(19 \%$ vs. $2 \%)$.
The methodology employed in PSED research can be obviously criticised because of its subjectivity. Nascent entrepreneurs chose only between two eventual sizes of their business: as big as possible, and the size that allows managing the business by the owner. The choice does not offer any actual information on the prospective size of the business. This "self-manageable" size of a business may vary greatly from one respondent to another, reflecting their attitudes, expectations, abilities, past experiences, business type or industry. Therefore, in terms of quantitative approach to business size, the PSED-based methodology does not prove to be useful. Traditional classification of small business, based on employment, turnover or asset value remains incompatible with it. On the other hand, it should be noted that its concept is deeply rooted in qualitative studies on small business. A small business, unlike its bigger counterparts, can be managed solely by the owner. A small business is not intended to grow above this "self-manageable" size as it would pose to entrepreneur a threat of losing direct control over it. This desire to exert full control over the business may be perceived as the essence of being a small business.

An alternative way of measuring growth aspirations of nascent entrepreneurs is adopted from studies on the early growth of a firm. In a number of publications dedicated to this topic, the size of a business is measured by the number of employees after five years of business operations.

Figure 2. Contextual typology of new ventures in PSED research

\begin{tabular}{|c|c|c|c|}
\hline & \multicolumn{2}{|c|}{ Growth aspirations } & \multirow[b]{2}{*}{ 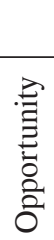 } \\
\hline 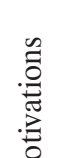 & $\begin{array}{l}\text { Opportunity-based } \\
\text { small business venture } \\
\text { (OSBV) }\end{array}$ & $\begin{array}{c}\text { Opportunity-based } \\
\text { entrepreneurial business venture } \\
(\mathrm{OEBV})\end{array}$ & \\
\hline 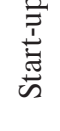 & $\begin{array}{l}\text { Necessity-based } \\
\text { small business venture } \\
(\mathrm{NSBV})\end{array}$ & $\begin{array}{c}\text { Necessity-based } \\
\text { entrepreneurial business venture } \\
(\mathrm{NEBV})\end{array}$ & 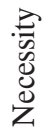 \\
\hline & Small business & Entrepreneurial business & \\
\hline
\end{tabular}

Source: Hechavarria, Schenkel and Matthews, 2009.

Wydział Zarządzania UW ～DOI 10.7172/1733-9758.2017.23.9 
An extensive critical review of this stream of research was presented by Delmar and Davidsson (Delmar and Davidsson, 2005). The criticism comes from a retrospective character of such research and can be attributed to two factors. Firstly, high growth aspirations revealed by such research can be - at least - a result of hindsight bias. Secondly, any sample in this kind of research is positively biased. This positive bias comes from the fact that samples are composed of businesses that were able to survive in the market for the first five years. That means, for instance, that business owners with really high growth aspirations may have given up their businesses when they realised their aspirations were unlikely to be met. Adopting and applying this methodology to nascent entrepreneurs eliminates its retrospective characteristics. Actual employment after five years is replaced by expectations regarding employment after five years of business operations. Samples consisting of nascent entrepreneurs only make hindsight bias irrelevant and also eliminate the above-mentioned problem of positive bias of research sample. The usefulness of this methodology has been proved through the GEM project (Bager and Schott, 2004). It can, of course, be still criticised because of its purely quantitative character and the fact that measuring growth with employment is associated with some shortcomings. Yet, despite this last argument, employment remains the most popular measure of growth.

\section{Methodology and Sample Selection}

Both methodological approaches discussed above offer valuable insights. Because of their different characters (qualitative - PSED, and quantitative - GEM), they can be perceived as complementary rather than competitive. That is why both ways of examining growth aspiration of nascent entrepreneurs are used in this paper.

Sample selection in research on nascent entrepreneurs is inherently problematic. Apart from all well-known problems with composing samples of actual entrepreneurs (van Stel, Cieślik and Hartog, 2010), the quality of being "nascent" additionally complicates the matter. Contrary to actual entrepreneurs, nascent entrepreneurs cannot usually be separated from the general population. Most of actions undertaken in order to set up own business do not expose the identity of a nascent entrepreneur; hence, there are no databases or registers that can be used to assist in composing a research sample. Samples made exclusively of nascent entrepreneurs are, therefore, rare (Delmar and Davidsson, 2000; Davidsson and Honig, 2003). That is why the samples used for this paper comprised 122 business students and 101 actual entrepreneurs with two years of experience in running their own business $(\mathrm{n}=223)$.

Business students are often used as proxies for actual entrepreneurs, and results of such studies are usually generalised over the general population (Tkachev and Kolvereid, 1999; Krueger, Reilly and Carsrud, 2000; Hemmasi and Hoelscher, 2005). The same arguments used for replacing entrepreneurs with business students are also valid for nascent entrepreneurs. Additionally, in the context of nascent entrepreneurship, two other arguments for using business students can be found. Firstly, it is known that entrepreneurial inclinations of students during their process of education have a significant and positive impact on their future entrepreneurial activities (McLarty, 2005; Gurol and Atsan, 2006). Since nascent entrepreneurship is just an initial stage of the entrepreneurial process, the link between students' entrepreneurial inclinations and the nascent entrepreneur status should be even stronger. Entrepreneurial students are more likely to take actions leading to starting their own business than to be actual entrepreneurs.

Secondly, students seem to be more suitable proxies for nascent entrepreneurs than for actual entrepreneurs because of their age. Studies show that the highest probability of achieving the status of a nascent entrepreneur is for individuals aged from 25 to 34 , whereas the probability of running own business peaks after 34 (Blanchflower, 2004). The age of students locates them in the close proximity to the maximum likelihood of becoming nascent entrepreneurs (Reynolds, Bygrave, Autio, and Hay, 2002; Bosma, Jones, Autio, and Levie, 2008). A complex justification for using convenience samples of students for researching nascent entrepreneurs can be found in Zięba (Zięba, 2015). 


\section{Results}

Both samples were investigated with regard to growth aspirations using PSEDbased and GEM-based methodologies. As can be seen in Table 1 and Table 2, growth aspirations among students are considerably higher than among entrepreneurs with two years of business experience. The significance of the observed differences is confirmed with the $\chi^{2}$ test. It should be noted here that in case of the PSED-based methodology the test was only applied to given answers (lack of an answer was omitted).

Table 1. Growth aspirations among students and entrepreneurs - PSED-based methodology

\begin{tabular}{|l|r|r|r|r|}
\hline \multirow{2}{*}{$\begin{array}{l}\text { Ultimate size } \\
\text { of business: }\end{array}$} & \multicolumn{2}{|c|}{$\begin{array}{c}\text { Students } \\
\text { sample }\end{array}$} & \multicolumn{2}{c|}{$\begin{array}{c}\text { Entrepreneurs } \\
\text { sample }\end{array}$} \\
\cline { 2 - 5 } & {$[\mathbf{n}]$} & \multicolumn{1}{c}{$[\%]$} & {$[\mathbf{n}]$} & {$[\%]$} \\
\hline $\begin{array}{l}\text { "as big as } \\
\text { possible" }\end{array}$ & 38 & 31 & 11 & 11 \\
\hline $\begin{array}{l}\text { "self- } \\
\text { manageable" }\end{array}$ & 81 & 66 & 89 & 88 \\
\hline no answer & 3 & 2 & 1 & 1 \\
\hline Total: & 122 & 100 & 101 & 100 \\
\hline \multicolumn{4}{|c|}{$\chi^{2}$ test: p-value $=0.0002$} \\
\hline
\end{tabular}

Source: own calculations.

Similarly, the lack of answers was excluded from the $c^{2}$ test in case of the GEM-based methodology, and this applies to all the following analyses. Additionally, one person from the students sample claiming not to employ anyone was also omitted in the test. Entrepreneurs that want to be just self-employed do not have any growth aspirations with regard to their business.

At first glance, the observed differences may seem easy to explain, because students - as opposed to actual entrepreneurs - may be not only overly optimistic with regard to growth aspirations but also simply careless. Not confronted with business reality and without any prior experience, they may find it difficult to be realistic about potential employment.

Surprisingly, student nascent entrepreneurs have similar growth aspirations as their colleagues who have not taken any action to start their business yet, regardless of which methodology is used to measure those aspirations. Any differences between them remain statistically insignificant. This shows again that nascent entrepreneurs cannot be easily distinguished from the general population. After excluding all students that did not start activities aimed at setting up own business, it is possible to compare growth aspirations of nascent entrepreneurs and actual entrepreneurs.

Table 2. Growth aspirations among students and entrepreneurs - GEM-based methodology

\begin{tabular}{|l|r|r|r|r|}
\hline \multirow{2}{*}{$\begin{array}{c}\text { Expected size } \\
\text { after 5 years } \\
\text { of operation: }\end{array}$} & \multicolumn{2}{|c|}{$\begin{array}{c}\text { Students } \\
\text { sample }\end{array}$} & \multicolumn{2}{|c|}{$\begin{array}{c}\text { Entrepreneurs } \\
\text { sample }\end{array}$} \\
\cline { 2 - 5 } & [n] & \multicolumn{1}{c}{ [\%] } & \multicolumn{1}{c|}{ [n] } & [\%] \\
\hline $\begin{array}{l}\text { self- } \\
\text { employment }\end{array}$ & 1 & 1 & 0 & 0 \\
\hline $1-5$ employees & 40 & 33 & 91 & 90 \\
\hline $\begin{array}{l}\text { 6-19 } \\
\text { employees }\end{array}$ & 57 & 47 & 8 & 8 \\
\hline $\begin{array}{l}20 \text { and more } \\
\text { employees }\end{array}$ & 22 & 18 & 1 & 1 \\
\hline no answer & 2 & 2 & 1 & 1 \\
\hline Total: & 122 & 100 & 101 & 100 \\
\hline \multicolumn{4}{|c|}{$\chi^{2}$ test: p-value $=0.0000$} \\
\hline
\end{tabular}

Source: own calculations.

In both samples, the majority of the respondents are interested in operating business of the size that can still be managed by the owner. Nevertheless, the share of nascent entrepreneurs who want their businesses to be as big as possible is three times greater than in case of actual entrepreneurs. High growth aspirations, expressed by giving up personal control in return for owning a business of a considerable size, are therefore much more prevalent among nascent entrepreneurs.

Higher growth aspirations of nascent entrepreneurs are even more evident when measured using the GEM-based methodology. It should be noted here that the expected employment after five years of operation is broken into three categories which do not reflect the traditional classification of business size (microfirm employing up to 9, small firm from 10 to 49, and medium one - from 50 to 259 employees). Hence, it is difficult to compare growth aspirations examined with this methodology with the size structure of the SME sector. 
Table 3. Growth aspirations of student nascent entrepreneurs and actual entrepreneurs - PSEDbased methodology

\begin{tabular}{|l|r|r|r|r|}
\hline \multirow{2}{*}{$\begin{array}{l}\text { Ultimate size } \\
\text { of business: }\end{array}$} & \multicolumn{2}{|c|}{$\begin{array}{c}\text { Student } \\
\text { nascent } \\
\text { entrepreneurs } \\
\text { sample }\end{array}$} & \multicolumn{2}{|c|}{$\begin{array}{c}\text { Entrepreneurs } \\
\text { sample }\end{array}$} \\
\cline { 2 - 5 } & {$[\mathbf{n}]$} & \multicolumn{1}{c}{$[\%]$} & {$[\mathbf{n}]$} & {$[\%]$} \\
\hline $\begin{array}{l}\text { "as big as } \\
\text { possible" }\end{array}$ & 12 & 32 & 11 & 11 \\
\hline $\begin{array}{l}\text { "self- } \\
\text { manageable" }\end{array}$ & 26 & 68 & 89 & 88 \\
\hline no answer & 0 & 0 & 1 & 1 \\
\hline Total: & 38 & 100 & 101 & 100 \\
\hline \multicolumn{4}{|c|}{$\chi^{2}$ test: p-value $=0.0037$} \\
\hline
\end{tabular}

Source: own calculations.

Table 4. Growth aspirations of student nascent entrepreneurs and actual entrepreneurs - GEMbased methodology

\begin{tabular}{|l|r|r|r|r|}
\hline \multirow{2}{*}{$\begin{array}{c}\text { Expected size } \\
\text { after 5 years } \\
\text { of operation: }\end{array}$} & \multicolumn{2}{|c|}{$\begin{array}{c}\text { Student } \\
\text { nascent } \\
\text { entrepreneurs } \\
\text { sample }\end{array}$} & \multicolumn{2}{|c|}{$\begin{array}{c}\text { Entrepreneurs } \\
\text { sample }\end{array}$} \\
\cline { 2 - 5 }$[\mathbf{[ n ]}$ & {$[\%]$} & {$[\mathbf{n}]$} & {$[\%]$} \\
\hline $1-5$ employees & 13 & 34 & 91 & 90 \\
\hline $\begin{array}{l}6-19 \\
\text { employees }\end{array}$ & 16 & 42 & 8 & 8 \\
\hline $\begin{array}{l}20 \text { and more } \\
\text { employees }\end{array}$ & 8 & 21 & 1 & 1 \\
\hline no answer & 1 & 3 & 1 & 1 \\
\hline Total: & 38 & 100 & 101 & 100 \\
\hline \multicolumn{4}{|c|}{$\chi^{2}$ test: p-value $=0.0000$} \\
\hline
\end{tabular}

Source: own calculations.

The vast majority of entrepreneurs $(90 \%)$ want their businesses to employ up to five persons, which means they generally want to manage a small microfirm. In the nascent entrepreneurs sample, such moderate aspirations are declared by every third person. Eight percent of entrepreneurs want to own a business the size of which allows for classifying it within the range between a big microfirm and a little small business (6-19 employees). The corresponding share in the nascent entrepreneurs sample is four times greater $-42 \%$ (sic!). This size is the most preferred among nascent entrepreneurs. Bigger businesses are generally beyond growth aspirations of actual entrepreneurs $1 \%$ of the sample is interested in owning such a relatively big business. Here again nascent entrepreneurs indicate their higher growth aspirations: more than $20 \%$ of them want to employ 20 and more persons.

As can be seen in Table 3 and Table 4 , growth aspirations of nascent entrepreneurs are undoubtedly higher than the ones of actual entrepreneurs. Having stated that, let us try to explain why those initially high growth aspirations among nascent entrepreneurs become significantly lower among actual entrepreneurs. Is it natural selection or adaptation?

This study cannot offer a direct answer to this question. It would require a longitudinal study on nascent entrepreneurs using a big research sample. Instead, an indirect answer can be offered, based on a few assumptions and the expected mortality rate of businesses.

Assumption 1: Let us assume that initially (before starting their business) growth aspirations among actual entrepreneurs were at the same level as they are now for nascent entrepreneurs.

Assumption 1 states that the sample of nascent entrepreneurs in this study is fully representative of the sample of entrepreneurs if the latter had been examined before they actually started their business. In other words, we assume that the observed differences in growth aspirations between our samples are the effect of time spent on running a business.

Assumption 2: Let us assume that the only mechanism beyond the observed changes is negative selection.

Possibly, the differences between samples with regard to growth aspirations can be a result of two mechanisms. Using assumption 2, we eliminate one of them to check whether it is possible to assign all the differences to the other mechanism.

Assumption 3: Let us assume that negative selection applies only to businesses owned by entrepreneurs with high growth aspirations.

Assumption 3 simplifies calculations regarding the mortality rate. Additionally, it allows minimising the required mortality rate. If this rate turns out to be unrealistically high under this assumption, then it would have to be even higher in real-world 
circumstances. That would mean that negative selection cannot be the only mechanism responsible for decreasing growth aspirations among entrepreneurs.

When the PSED-based methodology is used, it turns out that $32 \%$ of nascent entrepreneurs express high growth aspirations as compared to $11 \%$ of actual entrepreneurs. Under all the assumptions made above, a nearly $72 \%$ mortality rate over two years would be required to account for the observed differences.

The GEM-based approach suggests that low growth aspirations (less than 6 employees after five years of operation) are typical of $34 \%$ of nascent entrepreneurs and $90 \%$ of actual entrepreneurs. Given the three assumptions made above, a nearly 94\% mortality rate over two years would be required to account for the differences between the samples.

\section{Discussion}

The examined entrepreneurs have two-year experience in running their own business. This initial phase of running a business is the most demanding one. The risk of failure is relatively high then, and the culmination of failures appears after 6-8 quarters after starting the business (Cressy, 2006). Most of inefficient businesses have, therefore, been already eliminated from the market. Negative selection, however, cannot be claimed as the only reason for the observed differences. Even if the culmination of failures has already taken place, it seems completely unrealistic to have the mortality rate for a two-year period at the level of $72 \%$ (PSED-based methodology) or at the level exceeding 90\% (GEM-based methodology). The conclusion is that apart from negative selection, the process of adaptation plays an important role in decreasing growth aspirations of nascent entrepreneurs.

Out of the three assumptions made in this paper, two are questionable. Assumption 3 is clearly unrealistic, as low growth aspirations cannot completely guarantee business success. Low growth aspirations may indeed reduce the risk of failure, and obviously high growth aspirations may make business more risky. However, assigning all failures to the high growth aspirations part of the sample is doubtful. If assumption 3 is abandoned, the required mortality rate would have to be substantially higher, thus proving that Lamarckian adaptation is even a more important factor in explaining the fall in growth aspirations of nascent entrepreneurs.

Assumption 1 may be doubtful mostly because of the fact that student nascent entrepreneurs are not necessarily entirely representative of nascent entrepreneurs with other background. Accepting this assumption was, however, essential to perform the above analysis. The observed differences in growth aspirations between nascent entrepreneurs and actual entrepreneurs are quite substantial. Even if student nascent entrepreneurs were replaced by nascent entrepreneurs from the general population, it seems unlikely that such replacement would alter those differences in such a significant way as to change the conclusions of this paper.

The major limitation of this paper is the fact that it does not offer a direct answer to the question as to which mechanism, and to what extent, is responsible for decreasing growth aspirations of nascent entrepreneurs. With the samples used in this paper, only an indirect answer can be provided. Both Darwinian negative selection and Lamarckian adaptation are responsible for the observed decline in growth aspirations. In order to determine the extent to which each of those mechanisms is responsible for that decline, a completely different longitudinal study is needed.

\section{References}

Ajzen, I. (1985). From intentions to actions: A theory of planned behaviour. In: J. Kuhl and J. Beckmann, Action control: From cognition to behavior. Berlin: Springer-Verlag.

Bager, T. and Schott, T. (2004). Growth expectations by entrepreneurs in nascent, baby and mature firms: Analysis of the Global Entrepreneurship Monitor surveys in Denmark 2000-2003. Paper delivered at First GEM Research Conference, Berlin.

Blanchflower, D.G. (2004). Self-employment: More may not be better. NBER Working Paper, No. 10286

Bosma, N., Jones, K., Autio, E. and Levie, J. (2008). Global Entrepreneurship Monitor 2007 Executive report. Babson College, London Business School.

Coad, A. (2007). Firm growth: A survey (Document de Travail du Centre d'Economie de la Sorbonne). Paris: Centre National de la Recherche Scientifique. 
Cressy, R. (2006, March). Why do most firms die young? Small Business Economics, 26(2), 103-116.

Davidsson, P. and Honig, B. (2003). The role of social and human capital among nascent entrepreneurs. Journal of Business Venturing, 18(3), 301-331.

Delmar, F. and Davidsson, P. (2000). Where do they come from? Prevalence and characteristics of nascent entrepreneurs. Entreprenership \& Regional Development, 12(1), 1-23.

Delmar, F. and Davidsson, P. (2005). Firm size expectations of nascent entrepreneurs. Babson-Kauffmann Entrepreneurship Research Exchange Proceedings.

Gurol, Y. and Atsan, N. (2006). Entrepreneuria characteristics amongst university students: Some insights for entrepreneurial education and training in Turkey. Education + Training, 48(1), 25-38.

Hechavarria, D.M., Schenkel, M.T. and Matthews, C.H. (2009). Contextual motivation and growth aspirations among nascent entrepreneurs. In: Z. Acs and D. Audretsch (series eds.) International Studies in Entrepreneurship: vol. 23, New firm creation in the United States (pp. 35-49). New York: Springer Science + Business Media.

Hemmasi, M. and Hoelscher, M. (2005). Entrepreneurship research: Using students as proxies for actual entrepreneurs. Journal of Entrepreneurship Education, 8, 49-60.

Krueger, N. (1993, Fall). The impact of prior entrepreneurial exposure on perceptions of new venture feasibility and desirability. Entrepreneurship: Theory \& Practice, 18(1), 5-21.

Krueger, N.F., Reilly, M.D. and Carsrud, A.L. (2000). Competing models of entrepreneurial intentions. Journal of Business Venturing, 15(5-6), 411-432.

Kuehn, K.W. (2008). Entrepreneurial intentions research: Implications for entrepreneurship edu- cation. Journal of Entrepreneurship Education, 11, 87-98.

McLarty, R. (2005). Entrepreneurship among graduates: Towards a measured response. Journal of Management Development, 24(3), 223-238.

Reynolds, P.D., Bygrave, W.D., Autio, E., Cox, L.W. and Hay, M. (2002). Global Entrepreneurship Monitor 2002 Executive Report. Babson College, London Business School, Ewing Marion Kauffman Foundation.

Storey, D. (1994). Understanding the small business sector. International Thomson Business Press.

Tkachev, A. and Kolvereid, L. (1999). Self-employment intentions among Russian students. Entrepreneurship \& Regional Development: An International Journal, 11(3), 269-280.

van Stel, A., Cieślik, J. and Hartog, C. (2010) Measuring business ownership across countries and over time: Expanding the COMPENDIA data base. Zoetermeer: EIM Research Reports.

Wasilczuk, J.E. (2005). Wzrost matych $i$ średnich przedsiębiorstw. Aspekty teoretyczne i badania empiryczne. Gdańsk: Wydawnictwo Politechniki Gdańskiej.

Wasilczuk, J.E., Zięba, K. and Dominiak, P. (2008). Survey on SMEs growth in the Pomerania Region phase one: An intentional model of growth. USASBE 2008 Conference Proceedings (pp. 55-74). San Antonio, Texas: Small Business Advancement National Center, University of Arkansas.

Wasilczuk, J. and Zięba, K. (2014). The impact of urban localizations on the growth possibilities. In: I. Koładkiewicz and J. Cieślik (eds.), Shaping local business communities. Warszawa.

Zięba, K. (2015). Preprzedsiębiorczość (1st ed.). Gdańsk: Wydawnictwo Politechniki Gdańskiej. 